\title{
Investigating cold gelation properties of recombined highly concentrated micellar casein concentrate and cream for use in cheese making
}

\author{
Y. Lu, D. J. McMahon, ${ }^{1}$ and A. H. Vollmer \\ Western Dairy Center, Utah State University, Logan 84322-8700
}

\begin{abstract}
Highly concentrated micellar casein concentrate (HC-MCC), a potential ingredient for cheese making, contains $\sim 20 \%$ casein with $\sim 70 \%$ of serum proteins removed by microfiltration and diafiltration of skim milk, followed by vacuum evaporation. Our objective was to investigate cold gelation properties of recombined concentrated milk (RCM) by mixing thawed frozen HC-MCC and cream under different casein levels, $\mathrm{pH}$, and protein-to-fat ratios, and with addition of sodium citrate or calcium. The HC-MCC was recombined with cream using low shear at $50^{\circ} \mathrm{C}$ for $30 \mathrm{~min}$, and rheological measurements were conducted. Cold-gelling temperature [the temperature at which storage modulus $\left(\mathrm{G}^{\prime}\right)=$ loss modulus $\left(\mathrm{G}^{\prime \prime}\right)$ ] was linearly correlated with casein levels from 8.6 to $11.5 \%\left(\mathrm{R}^{2}=0.71\right), \mathrm{pH}$ from 6.6 to $7.0\left(\mathrm{R}^{2}=0.96\right)$, and addition of sodium citrate from 0 to $0.36 \mathrm{mmol} / \mathrm{g}$ of casein $\left(\mathrm{R}^{2}=0.80\right)$. At $\mathrm{pH} 7.0$, gelation occurred at 12,26 , and $38^{\circ} \mathrm{C}$ with 9,10 , and $11 \%$ casein, respectively. At pH 6.6, 6.8, and 7.0, RCM with $12 \%$ casein gelled at a mean temperature of 12,26 , and $37^{\circ} \mathrm{C}$, respectively. Adding calcium chloride at 0.17 $\mathrm{mmol} / \mathrm{g}$ of casein significantly increased cold-gelling temperature from 18 to $\geq 50^{\circ} \mathrm{C}$, whereas no significant change was observed at levels up to $0.12 \mathrm{mmol} / \mathrm{g}$ of casein. Different protein to fat ratios ranging from 0.8 to 1.2 did not significantly influence gelling temperature. In transmission electron micrographs of RCM with $12 \%$ casein, casein micelles were nonspherical and partially dissociated into small protein strands. Upon addition of calcium chloride at $0.21 \mathrm{mmol} / \mathrm{g}$ of casein, casein micelles were more spherical and retained colloidal structure with the presence of aggregated casein micelles. These gelation processes of RCM with or without addition of trisodium citrate were both reversible. We propose that cold gelation of RCM occurs when protein strands that have been partially released from the casein micelles entangle, restrict their mobility, and
\end{abstract}

Received December 21, 2015.

Accepted March 4, 2016.

${ }^{1}$ Corresponding author: Donald.mcmahon@usu.edu form a fine-stranded gel network. Upon addition of high levels of calcium, cold gelation was promoted presumably through direct aggregation of casein micelles. Understanding cold gelation properties can facilitate potential use of RCM in cheese making.

Key words: micellar casein, microfiltration, gelation, microstructure

\section{INTRODUCTION}

Ultrafiltration technology has been used in cheese making to increase cheese yield and daily milk processing capacity since the 1970s (Ernstrom et al., 1980; Kosikowski et al., 1985; Govindasamy-Lucey et al., 2004). The practical limit for concentration by UF is about $5 \times$ (van Leeuwen et al., 1990). Hard and semi-hard cheeses can be made using diafiltrated and preacidified UF retentate $(\sim 5 \times)$ to reduce lactose and calcium phosphate contents, resulting in sufficient whey expulsion after rennet coagulation to achieve the final moisture content (Sutherland and Jameson, 1981). Concentrating milk to this level requires use of specialized equipment to handle the higher viscosity compared with milk, and because it is more difficult to expel whey from curd made from a 4 to $6 \times$ retentate. An additional challenge is that having more serum proteins retained in the cheese slows changes in texture and flavor development during aging (Creamer et al., 1987; Lelievre et al., 1990; Bastian et al., 1991).

In the 1990s, microfiltration (MF) was used to concentrate skim milk and produce phosphate caseinate (Pierre et al., 1992), which is commonly called micellar casein concentrate (MCC) in the United States (Saboyainsta and Maubois, 2000; Nelson and Barbano, 2005; Hurt et al., 2010). Unlike UF, MF only concentrates micellar casein and does not concentrate serum proteins, up to $95 \%$ of which can be removed with extensive diafiltration (Pierre et al., 1992; Hurt et al., 2010; Marella et al., 2013). Therefore, MCC obtained through a MF process is potentially more suitable for cheese making than UF retentate.

In a similar way to using UF retentate, MF retentate with a low concentration level of 1.2 to $1.8 \times$ is 
suitable for increasing cheese yield (Neocleous et al., 2002a,b; Govindasamy-Lucey et al., 2004). Typically, MCC manufactured using MF is only concentrated to 3 to $4 \times$ (Nelson and Barbano, 2005; Amelia et al., 2013; Hurt et al., 2015), whereas higher concentrations of 7 to $8 \times$ can be achieved by using milk acidification or further concentrating using UF or evaporation (Brandsma and Rizvi, 1999; Amelia and Barbano, 2013; Lu et al., 2015). Cheese making using milk retentate with high concentration factors such as $8 \times \mathrm{MF}$ retentate is difficult and requires specialized equipment in manufacture, and therefore is not widely used in industry (Brandsma and Rizvi, 1999; Fox et al., 2000; Brandsma and Rizvi, 2001). Medium concentration factor (4 to $5 \times)$ of UF retentate is used commercially to produce high-moisture cheese such as quark, cream, and Feta cheese but is not used widely for semi-hard or hard rennet-curd cheese due to changes in cheese texture, flavor, and functionality (Green et al., 1981; Fox et al., 2000). Without the interference of serum protein, MF retentate with medium concentration has the potential to make cheese using conventional cheese making equipment while retaining cheese quality.

Because of the fouling issues caused by the fat when microfiltering whole milk, it is more feasible to use an MF skim milk concentrate and recombine it with cream for use in cheese making (Brandsma and Rizvi, 2001; Neocleous et al., 2002b; Govindasamy-Lucey et al., 2007). There has been some research using recombined MF retentate and cream to make Cheddar (St-Gelais et al., 1995; Neocleous et al., 2002a,b), Mozzarella (Garem et al., 2000; Brandsma and Rizvi, 2001), and pizza cheese (Govindasamy-Lucey et al., 2007). A highly concentrated micellar casein concentrate (HCMCC) containing $\sim 23 \%$ (wt/wt) protein has been manufactured through MF, diafiltration, and vacuum evaporation of skim milk (Lu et al., 2015). The recombined concentrated milk (RCM) obtained by mixing $\mathrm{HC}-\mathrm{MCC}$ with cream is very suitable for cheese making

Table 1. Composition of highly concentrated micellar casein concentrate (HC-MCC) made using microfiltration and vacuum evaporation

\begin{tabular}{lc}
\hline Component & HC-MCC \\
\hline Total solids \% & 30.14 \\
Fat, \% & 0.94 \\
Total N, \% & 23.02 \\
Noncasein N, \% & 2.30 \\
NPN, \% & 0.32 \\
Casein N/total N & 0.90 \\
Lactose, \% & 3.79 \\
Organic acids, \% & 0.39 \\
Ash, \% & 2.33 \\
Calcium, \% & 0.72 \\
\hline
\end{tabular}

because of its high casein level $(\sim 20 \% \mathrm{wt} / \mathrm{wt})$ and low serum protein level $(<2 \% \mathrm{wt} / \mathrm{wt})$. However, HC-MCC tends to gel at temperatures below $50^{\circ} \mathrm{C}$, which can make it problematic for use in cheese making ( $\mathrm{Lu}$ et al., 2015). Our objective was to investigate the effect of casein levels, $\mathrm{pH}$, protein-to-fat ratios, and addition of citrate or calcium on cold gelation properties of RCM. Thermal reversibility and microstructure of RCM gel were also studied to better understand the factors that affect cold gelation.

\section{MATERIALS AND METHODS}

\section{HC-MCC Manufacture}

The HC-MCC was manufactured by MF and diafiltration of skim milk into MCC, followed by further condensation through vacuum evaporation as described by $\mathrm{Lu}$ et al. (2015). Pasteurized skim milk $\left(72^{\circ} \mathrm{C}\right.$ for 20 s) was processed into MCC in a 4 -vessel, continuous MF unit (Filtration Engineering Inc., Champlin, MN) at feed temperature of 18 to $20^{\circ} \mathrm{C}$, base line pressure of $35 \mathrm{kPa}$, differential pressure of $103 \mathrm{kPa}$, and a volume reduction of 4.0. Diafiltration was carried out at a level of $100 \%$ (based on volume of skim milk) with 20,30, 30 , and $20 \%$ of the diafiltration water added at vessels $1,2,3$, and 4, respectively. During start-up, the feed and circulating boost pumps were sequentially started and the combined MF concentrate obtained from all 4 vessels was recycled back to the balance tank until the desired concentration factor was achieved. After about 10 min, diafiltration was started and after about 30 min, when volume reduction of 4.0 was reached, the MF concentrate was collected in a 2,000-L double-jacketed tank. Based on the mass of serum protein collected in the permeate relative to the mass of serum protein in the pasteurized skim milk, 70 to $75 \%$ of the serum protein present in the skim milk was removed during the MF process. The composition of the skim milk and MF retentate are shown in Table 1. The HC-MCC was transferred to 1.89 - L containers, frozen at $-20^{\circ} \mathrm{C}$, shipped from South Dakota State University (Brookings) to Utah State University (Logan), and stored at $-20^{\circ} \mathrm{C}$ until further analysis. The composition of the HC-MCC is shown in Table 1.

\section{Composition Analysis}

Compositions of pasteurized skim milk, MF retentate, and HC-MCC were analyzed. Total solids, total fat, and ash were analyzed as described by Hooi et al. (2004). Kjeldahl analysis was used to determine total N, noncasein N, and NPN (Hooi et al., 2004). Lactose 
and organic acids were determined using an HPLCbased method (Upreti et al., 2006; Lu et al., 2015). A 300- $\times$ 7.80-mm ion exclusion column (ROAOrganic Acid, Phenomenex Inc., Torrance, CA) at $65^{\circ} \mathrm{C}$ with sulfuric acid $(0.013 \mathrm{~N})$ mobile phase at a flow rate of $0.6 \mathrm{~mL} / \mathrm{min}$ was used. The mobile phase was $360 \mu \mathrm{L}$ of sulfuric acid (Sigma-Aldrich, St. Louis, MO) dissolved in $1 \mathrm{~L}$ of water (Thermo Fisher Scientific, Pittsburgh, PA). Calcium was determined by atomic absorption spectroscopy (AAnalyst 200, PerkinElmer Instruments LLC, Waltham, MA) at a wavelength of $423 \mathrm{~nm}$ (Metzger et al., 2000).

\section{Rheological Properties}

One-hundred-gram portions of frozen HC-MCC ( $23 \%$ protein) were partially thawed at room temperature $\left(\sim 22^{\circ} \mathrm{C}\right)$. The RCM was made by mixing $\mathrm{HC}-\mathrm{MCC}$ ( $\sim 18.5$ to $27.5 \mathrm{~g}$ ), warm cream (32 to $44 \%$ fat, $50^{\circ} \mathrm{C}$; Aggie Creamery, Utah State University, Logan), and skim milk (purchased from a local supermarket) to reach casein levels from 8.6 to $12.1 \%$ with constant protein-to-fat ratios of $0.8,1.0$, and 1.2 , and optional addition of trisodium citrate $(0.08 \mathrm{mmol} / \mathrm{g}$ of casein; Thermo Fisher Scientific, Fair Lawn, NJ). Another batch of RCM was made by mixing cream $(20.4 \mathrm{~g})$ and skim milk $(2.1 \mathrm{~g})$ with $0,0.13,0.26$, or $0.36 \mathrm{mmol} / \mathrm{g}$ of casein of $\mathrm{pH}$-adjusted citrate, or with $0.08,0.12$, or $0.17 \mathrm{mmol} / \mathrm{g}$ of casein of dihydrate calcium chloride (J. T. Baker, Phillipsburg, NJ), followed by addition of $\mathrm{HC}-\mathrm{MCC}(27.5 \mathrm{~g})$. The RCM was heated to $50^{\circ} \mathrm{C}$ at low shear using a magnetic stirrer $(\sim 800 \mathrm{rpm})$, and $\mathrm{pH}$ was adjusted to 7.0,6.8, and 6.6 with $1 N \mathrm{NaOH}$ as needed. Protein content of diluted RCM was tested in triplicate using a rapid protein analyzer (Sprint, CEM Corp., Matthews, NC).

\section{Gelation Temperature and Thermal Reversibility}

Cold-gelling temperature (CGT) and thermal reversibility were measured using a magnetic bearing rheometer (model AR-G2; TA Instruments, New Castle, DE) as described by Lu et al. (2015). After stirring at $50^{\circ} \mathrm{C}$ for $30 \mathrm{~min}, 7.5 \mathrm{~mL}$ of $\mathrm{RCM}$ was poured into the coaxial cylinder that was already set at $50^{\circ} \mathrm{C}$, followed by cooling to $5^{\circ} \mathrm{C}$ at $1^{\circ} \mathrm{C} / \mathrm{min}$. Strain was set at $0.5 \%$ and frequency at $1 \mathrm{~Hz}$. The sample was covered with a solvent trap immediately after sample addition to prevent evaporation. The CGT was determined as the temperature at which storage modulus $\left(\mathbf{G}^{\prime}\right)$ equaled loss modulus $\left(\mathbf{G}^{\prime \prime}\right)$. Thermal reversibility was determined by cooling the mixture from 50 to $5^{\circ} \mathrm{C}$, holding at $5^{\circ} \mathrm{C}$ for $30 \mathrm{~min}$, heating to $50^{\circ} \mathrm{C}$, holding at $50^{\circ} \mathrm{C}$ for
$30 \mathrm{~min}$, followed by another round of cooling, holding, and heating steps at the rate of $1^{\circ} \mathrm{C} / \mathrm{min}$. The CGT was measured using triplicate batches of RCM and thermal reversibility using duplicate batches of RCM.

\section{Transmission Electron Microscopy}

Frozen HC-MCC was partially thawed at room temperature; then, $55.0 \mathrm{~g}$ of HC-MCC was mixed with $39.5 \mathrm{~g}$ of warm $\left(50^{\circ} \mathrm{C}\right)$ cream $(38 \%$ fat $)$ and $5.5 \mathrm{~g}$ of skim milk, with optional addition of $0.37 \mathrm{~g}$ of calcium chloride. The mixture was stirred at $50^{\circ} \mathrm{C}$ for $30 \mathrm{~min}$, poured into a Petri dish to about $1 \mathrm{~mm}$ thickness, and allowed to gel at room temperature $\left(\sim 22^{\circ} \mathrm{C}\right)$ for $20 \mathrm{~min}$. The gel sample was chemically fixed, processed, and analyzed by transmission electron microscopy (TEM), and digital images were captured as described by Lu et al. (2015).

\section{Statistical Analysis}

Linear regression was performed to investigate the effects of different casein levels, $\mathrm{pH}$, and citrate addition on CGT and $G^{\prime}$. Effects of protein to fat ratios and addition of calcium chloride on CGT and $\mathrm{G}^{\prime}$ were studied using a completely randomized design. Data were analyzed for statistical significance at 95\% confidence level using PROC GLM function in SAS software (version 9.3, SAS Institute Inc., Cary, NC). Significance was declared at $P<0.05$. Post hoc means comparisons were made based on $P$-values $(\alpha=0.05)$ using TukeyKramer adjustment to obtain differences of least mean squares.

\section{RESULTS AND DISCUSSION}

After making RCM by mixing HC-MCC with cream at $50^{\circ} \mathrm{C}$, the RCM formed into a gel upon cooling in a similar manner to the cold gelation previously observed for $\mathrm{HC}-\mathrm{MCC}$ ( $\mathrm{Lu}$ et al., 2015). The temperature at which cold gelation of RCM occurred depended on the concentration of casein levels, $\mathrm{pH}$, and calcium status.

\section{Microstructure of Cold-Gelled RCM}

Fat droplets ranging from 1 to $12 \mu \mathrm{m}$ in diameter were observed in the low-magnification electron micrographs of cold-gelled RCM (Figure 1A and B). In the high-magnification micrographs, which were used to study casein micelle appearance, the regions of the sample examined contained only casein micelles.

When cold-gelled RCM was examined using TEM (Figure 1), we observed that the casein micelles were 
nonspherical and had a more ragged and open structure compared with a gel formed by cooling HC-MCC (Figure 2). In the gelled HC-MCC (containing 20.7\% casein), most of the protein was contained within the casein micelles with a small amount located between the close-packed casein micelles. We had expected that when mixing the HC-MCC with cream, the colloidal nature of the casein micelles would be retained, because the serum phase of cream would provide the same calcium phosphate equilibrium as occurs in milk. Instead, the caseins in the RCM appeared to be partially dissociated, with a greater proportion of smaller, less electrondense protein material (i.e., the proteins were lighter gray). This is indicative of less heavy metal staining of the proteins, and suggests a more open structure with reduced crosslinking of protein strands via calcium phosphate. When $0.21 \mathrm{mmol}$ of calcium chloride/g of casein was added to RCM (Figure 1B, D, and F), there was a restoration of the casein into colloidal particles that was more typical of previous observations for skim milk and ultrafiltered milk (Olson, 1992; Karlsson et al., 2007; McMahon et al., 2009; Lu et al., 2015).

Because the RCM contained only $12.6 \%$ casein (about half of the casein level in HC-MCC), there was a larger relative distance between casein micelles in RCM gels (Figure 1) compared with HC-MCC gels (Figure 2). Lu et al. (2015) suggested that HC-MCC undergoes cold gelation because the casein micelles are closely packed
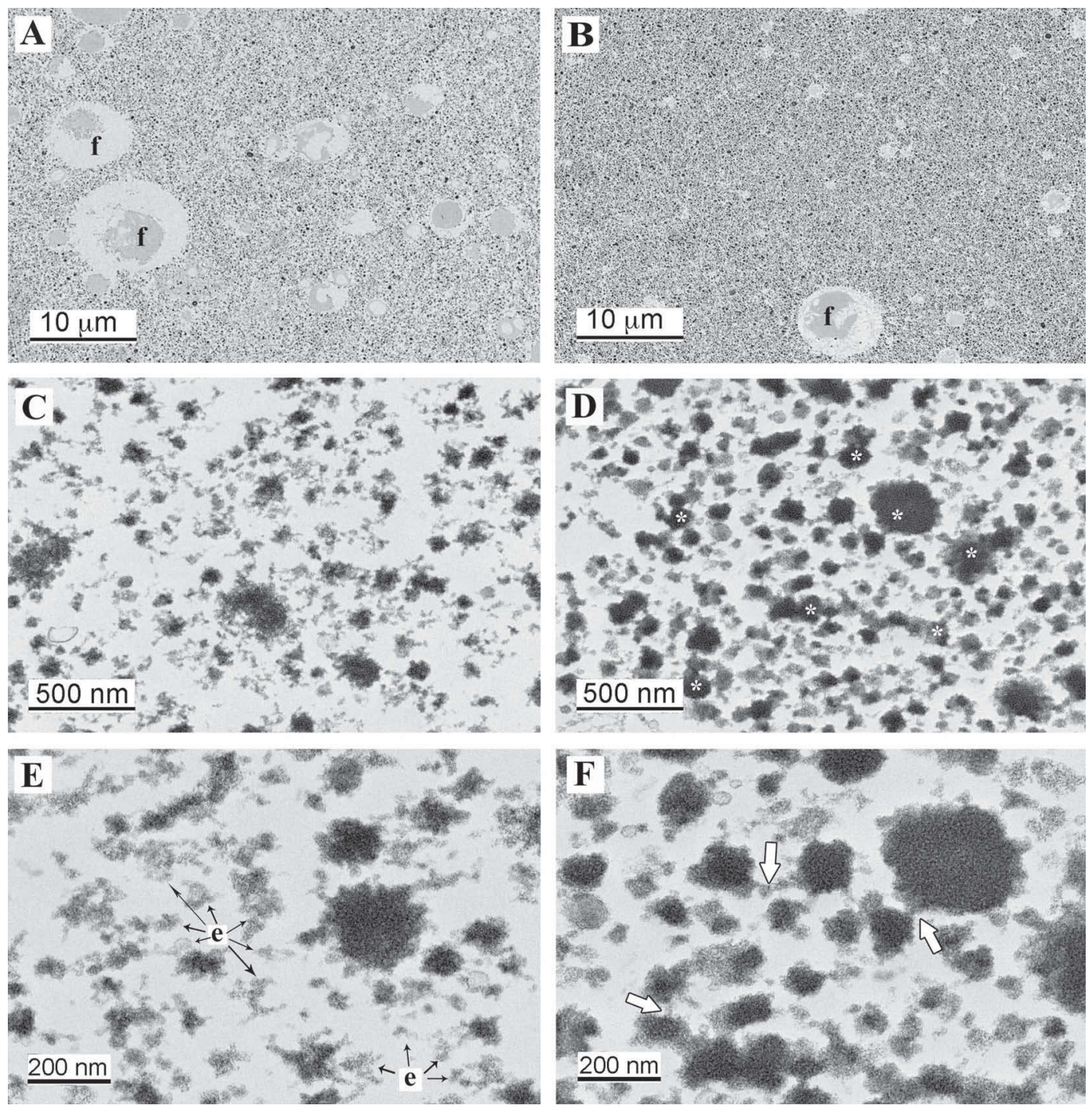

Figure 1. Transmission electron micrographs of cold-gelled (at $\left.\sim 21^{\circ} \mathrm{C}\right)$ recombined concentrated milk $(12 \%$ casein, casein to fat ratio of 0.8 , $\mathrm{pH}$ of 7.0) with (B, D, and F) or without (A, C, and E) addition of $0.21 \mathrm{mmol}$ of casein $/ \mathrm{g}$ of calcium chloride $(\mathrm{f}=\mathrm{fat}$ globules, e $=$ loosely entangled protein, white arrows = chains of protein located between protein stains, asterisks = aggregated casein micelles). 

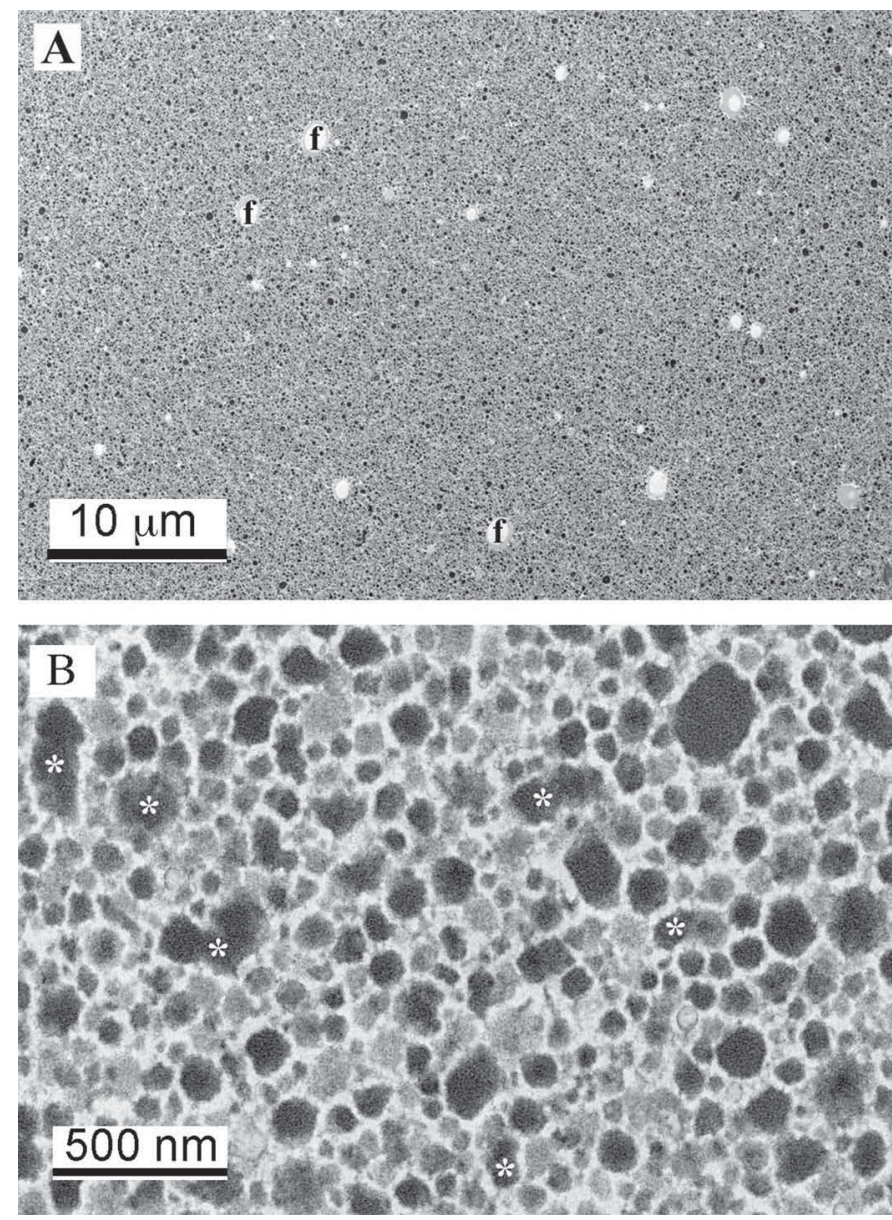

Figure 2. Transmission electron micrographs of cold-gelled micellar casein concentrate showing casein micelles (gray-black) of various sizes, including some casein micelles that appear aggregated (asterisks), as well as some very small milkfat globules (letter f).

together, causing steric interference between their peripheral protein tendrils. The reason for gelation of RCM when the casein micelles are spaced further apart is not as apparent.

Compared with the observed microstructure of other types of milk gels, the RCM gels contain many more small protein strands. In most cases, there was a lack of direct aggregation between neighboring casein micelles. This is opposite to what has been observed for milk gels formed by rennet or acid coagulation of milk. For example, in rennet-coagulated milk, the casein micelles are more spherical and occupy a smaller volume fraction than those in RCM, but they are linked together into chains formed by direct aggregation of the casein micelles (Figure 3; unpublished data, A. H. Vollmer). Such renneted casein micelles have had $\kappa$-casein macropeptides cleaved from their periphery and expose hydrophobic regions of para-k-casein. Then, driven by the entropic effects of hydrophobic regions on water, the renneted casein micelles form into clusters and chains interlinking with each other.

The importance of hydrophobic-induced aggregation between renneted casein micelles is easily observed by the acceleration of aggregation as temperature is increased and the delay, or inhibition, of aggregation
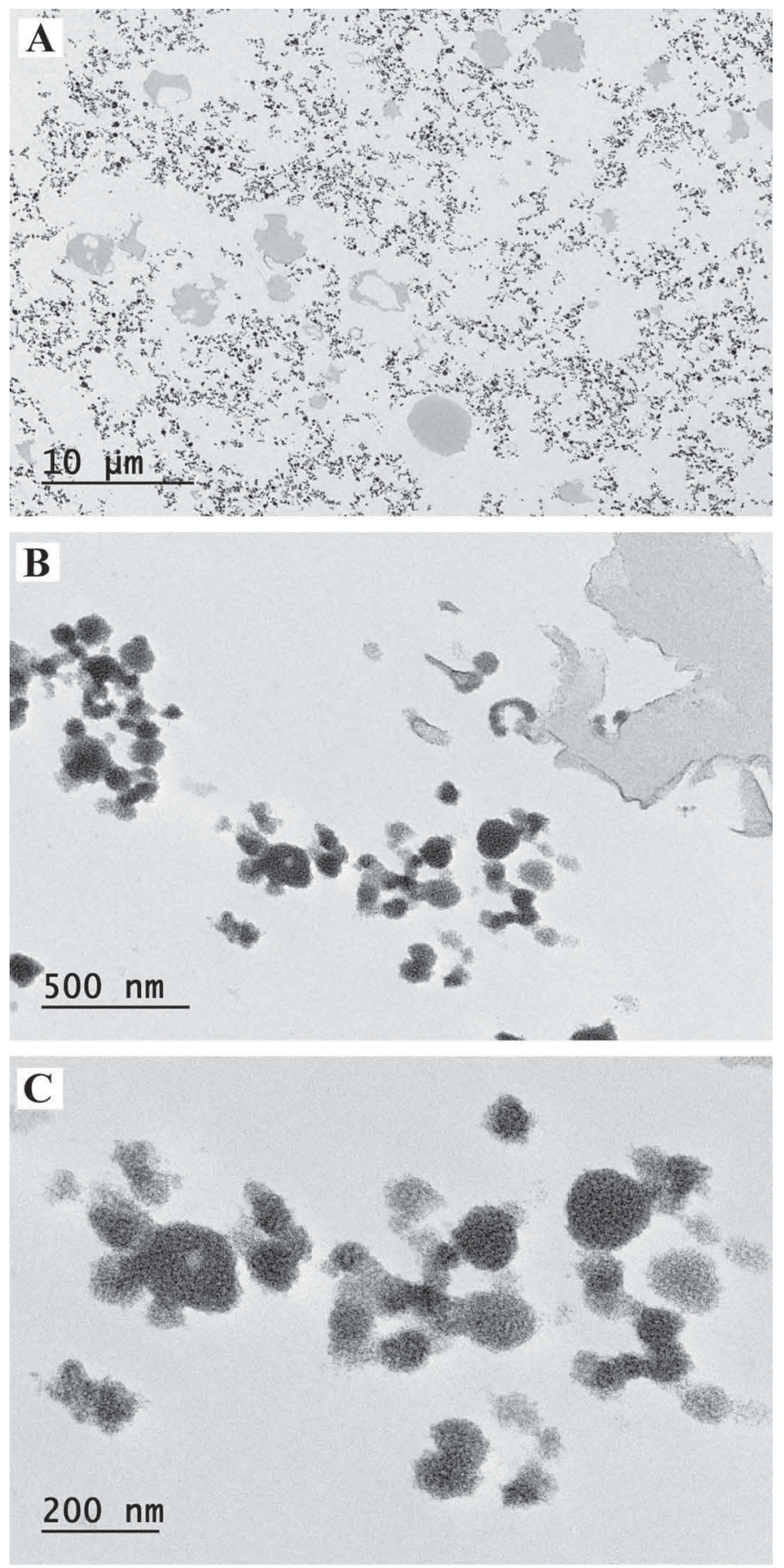

Figure 3. Transmission electron micrographs of milk gel coagulated for $30 \mathrm{~min}$ after rennet addition at $31^{\circ} \mathrm{C}$. 
as the milk temperature is lowered. The opposite occurs for both HC-MCC and RCM of sufficiently high protein concentration. At high temperature, there is no aggregation but it occurs as temperature is lowered and a gel is formed. The temperature dependence of hydrophobic interactions causes the proteins within the casein micelles to be more tightly bound to each other and to make the micelles more stable. At cooler temperatures, the proteins strands are less tightly bound within the casein micelles, allowing protein strands to extend outward from the periphery and then to interact (possibly via hydrogen bonding) to form the network structure of the cold-induced gels.

In milk gels formed by acidification at 20 or $30^{\circ} \mathrm{C}$, casein micelles are circular and directly form chains (Figure 4; McMahon et al., 2009). In this case, however, it is not known what rearrangements have occurred in the casein micelle structure when the $\mathrm{pH}$ of the milk is lowered to 4.8. There is an initial dissociation of protein from the casein micelles as milk is acidified to $\sim \mathrm{pH} 5.2$, and then, as $\mathrm{pH} 4.8$ is approached, the proteins associate again into spherical colloidal particles just before formation of the gel network.

Casein micelles in milk have been observed using TEM to have a somewhat spherical structure and, depending on resolution, appear to have a relatively smooth periphery in their native form (McMahon et al., 2009; McMahon and Oommen, 2013). Nonspherical casein micelles or small strands of proteins are considered as nonnative or dissociated structures and have been observed in skim milk treated with high pressure ( 150 MPa; Oommen, 2004; Knudsen and Skibsted, 2010). Thin strands of protein are also observed in sodium caseinate solutions (Oommen, 2004; Knudsen and Skibsted, 2010).

Dissociated casein micelles in RCM can be attributed to the calcium reduction $(\sim 22 \%)$ that has occurred during microfiltration with diafiltration during manufacture of the HC-MCC. Extensive diafiltration or washing is commonly used to reduce the levels of lactose and soluble calcium. There is generally $1.3 \mathrm{mmol}$ of calcium per gram of casein in milk, of which about two-thirds (i.e., $\sim 0.9 \mathrm{mmol} / \mathrm{g}$ of casein) is bound to casein within the casein micelles and is known as colloidal calcium phosphate (CCP; Singh et al., 1996). As calcium is removed, CCP is solubilized from the casein micelles to maintain ionic calcium and phosphate at their solubility limit, eventually resulting in dissociation of casein micelles (Lucey and Horne, 2009). Loss of CCP is known to cause dissociation of casein micelles in milk protein concentrate (MPC) and in casein micelles dispersions dialyzed against water (McMahon and Oommen, 2008; Kaliappan and Lucey, 2011).
In transmission electron micrographs of calciumdepleted casein micelles, small protein clusters less than $50 \mathrm{~nm}$ in size were observed (Oommen, 2004; McMahon and Oommen, 2013). Therefore, dissociated casein micelles caused by calcium reduction during HC-MCC processing can be present as nonspherical clusters or small protein strands. However, it is interesting that the casein micelles in HC-MCC would dissociate so extensively in cream, given that the ionic strength of milk was maintained. In HC-MCC gels with $20.7 \%$ casein, most casein micelles appeared intact without any apparent dissociation (Figure 2). Also in comparison, concentrated casein micelles are widely used in casein micelle studies in which they are suspended in milk permeate, without any dissociation of casein micelles being reported (Pierre and Brule, 1981; Farrell et al., 1988).

Compared with RCM without calcium addition, we observed a smaller proportion of less electron-dense protein strands but a higher proportion of aggregated colloidal particles (Figure 1D, asterisks) and small protein strands. Some of these protein strands were located between and appeared to connect adjacent casein micelles (Figure 1F, white arrows). Casein micelles appeared to be less electron dense (suggesting they contained fewer protein molecules), and their peripheral edges were less spherical with a more open structure than in the HCMCC gel (Figure 2). Addition of calcium may increase calcium-mediated bridges between negatively charged protein side chains such as carboxyl or phosphoserine groups, resulting in aggregation of dissociated casein micelles.

\section{Factors Influencing Cold Gelation}

Different Casein Levels. The CGT was linearly correlated $(P<0.001)$ with casein concentration in RCM (Figure 5). The mixture with mean casein levels of 9,10 , and $11 \%$ gelled at mean temperatures of 12 , 26 , and $38^{\circ} \mathrm{C}$, respectively. For every percentage-unit increase of casein level, mean CGT increased about $5^{\circ} \mathrm{C}$. Although $\mathrm{G}^{\prime}$ at $\mathrm{CGT}$ was also linearly associated $(P<0.001)$ with casein levels in RCM, the change of $\mathrm{G}^{\prime}$ was relatively small $(\sim 2 \mathrm{~Pa})$ for every 1 -percentage-unit change of casein level.

The CGT has been reported to be linearly correlated with protein concentration in $\mathrm{HC}-\mathrm{MCC}$ gel, resulting from steric interference between overlapping protuberances on the periphery of closely packed casein micelles (Lu et al., 2015). Although casein micelles were not as closely packed in RCM as in HC-MCC, the strands of dissociated casein micelles might also cause steric hindrance by limiting movement of other nearby strands or particles. The higher the casein level in the mixture, 
the shorter the distance between surrounding caseins, the sooner steric interference reduces casein mobility, and the higher the temperature at which CGT occurs.

Different Protein to Fat Ratios. Neither CGT nor $\mathrm{G}^{\prime}$ at $\mathrm{CGT}$ were significantly $(P>0.05)$ influenced by different protein to fat ratios ranging from 0.8 to 1.2 (Table 2), with mean CGT of $31^{\circ} \mathrm{C}$ and $\mathrm{G}^{\prime}$ of $11 \mathrm{~Pa}$. This indicates that within the testing range of casein levels in the nonfat portion from 12.0 to $12.6 \%$ and fat levels from 10.5 to $15 \%$, there was no significant influence on
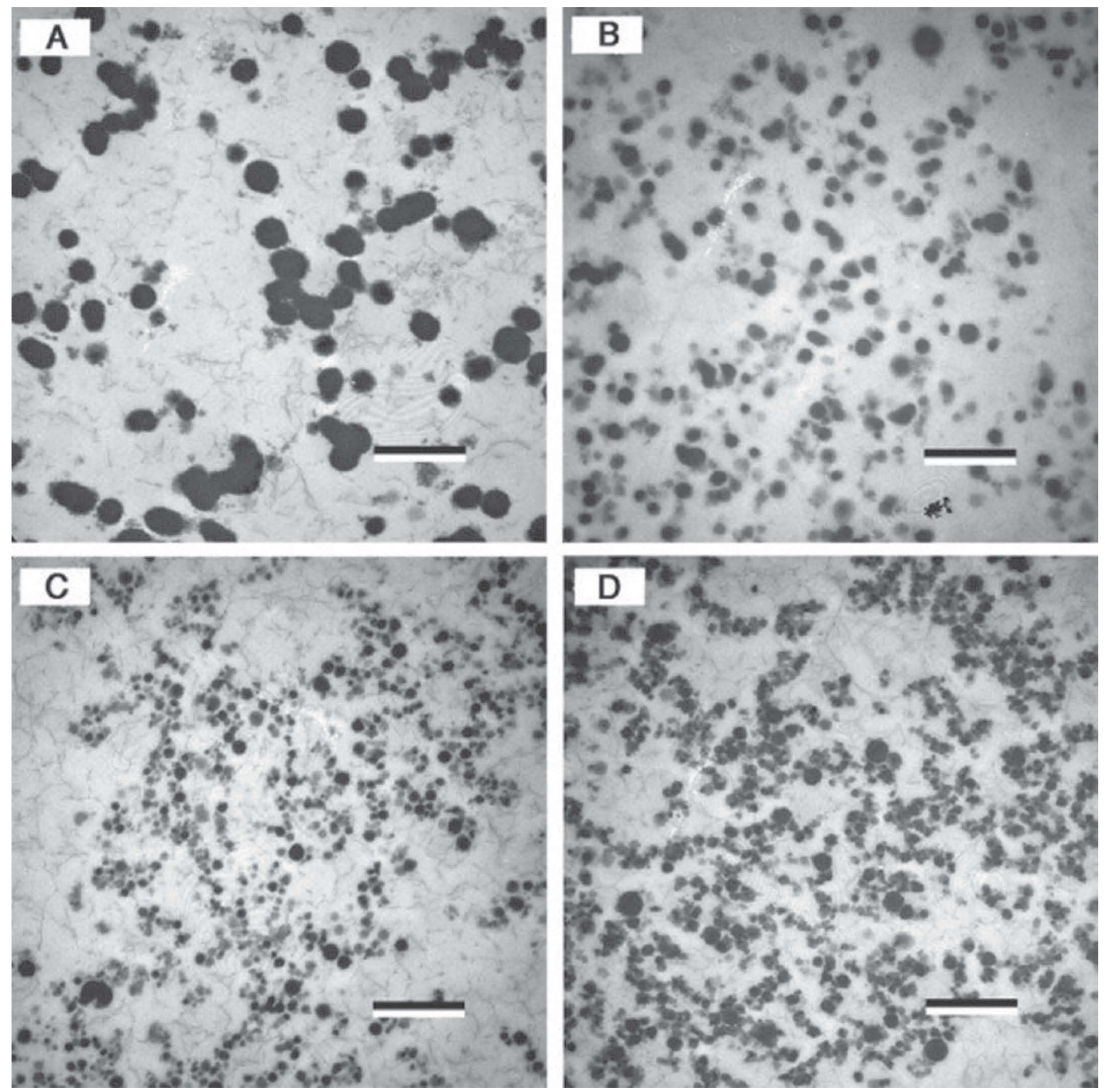

Figure 4. Transmission electron micrographs of acid milk gels at $\mathrm{pH} 4.8$ formed after acidification of skim milk by glucono- $\delta$-lactone at $(\mathrm{A})$ $40^{\circ} \mathrm{C}$, (B) $30^{\circ} \mathrm{C}$, (C) $20^{\circ} \mathrm{C}$, and (D) $10^{\circ} \mathrm{C}$ (bar $=1 \mu \mathrm{m}$ ). Reprinted with permission from McMahon et al. (2009). 
Table 2. Different protein to fat ratios (P:F), casein and fat levels, and casein levels in nonfat portion (casein \% in NF) in recombined concentrated milk at $\mathrm{pH} 7.0$, determined upon cooling from $50^{\circ} \mathrm{C}$ to $5^{\circ} \mathrm{C}$ at $1^{\circ} \mathrm{C} / \mathrm{min}$ using a strain of $0.5 \%$ and a frequency of $1 \mathrm{~Hz}$

\begin{tabular}{lccc}
\hline P:F & Casein $\%$ & Fat $\%$ & $\begin{array}{c}\text { Casein } \% \\
\text { in NF }\end{array}$ \\
\hline 0.8 & 10.7 & 15.0 & 12.6 \\
1.0 & 10.7 & 12.3 & 12.1 \\
1.2 & 10.8 & 10.5 & 12.0 \\
\hline
\end{tabular}

steric interference between casein micelles. The lack of significant effect of protein-to-fat ratio was probably due to the small testing range used in this study, which considered levels relevant to cheese manufacture.

Different $\boldsymbol{p H}$. The CGT was in a linear relationship $(P<0.001)$ with $\mathrm{pH}$ (Figure 6$)$. At $\mathrm{pH} 7.0,6.8$, and $6.6, \mathrm{RCM}$ gelled at a mean temperature of 37,26 , and $12^{\circ} \mathrm{C}$, respectively. For every 0.1-unit decrease in $\mathrm{pH}$, mean CGT decreased about $7^{\circ} \mathrm{C}$. When the $\mathrm{pH}$ of RCM was reduced to 6.5 , gelation did not occur until the mixture was cooled to $5^{\circ} \mathrm{C}$. Although $\mathrm{G}^{\prime}$ at $\mathrm{CGT}$ was also linearly associated $(P<0.05)$ with $\mathrm{pH}$ in RCM, the change of $\mathrm{G}^{\prime}$ was relatively small $(1 \mathrm{~Pa})$ for every 0.1 -unit change of $\mathrm{pH}$.

Increasing $\mathrm{pH}$ from 6.7 to 7.1 was associated with increasing levels of caseins (i.e., $\alpha_{S^{-}} \mathrm{CN}$ and $\beta-\mathrm{CN}$ ) dissociating from casein micelles, resulting in decreasing diameter of casein micelle in recombined skim milk and micellar casein solutions (Anema and Klostermeyer, 1997; Post et al., 2012; Anema et al., 2014). Dissociation of casein micelles could increase the number of

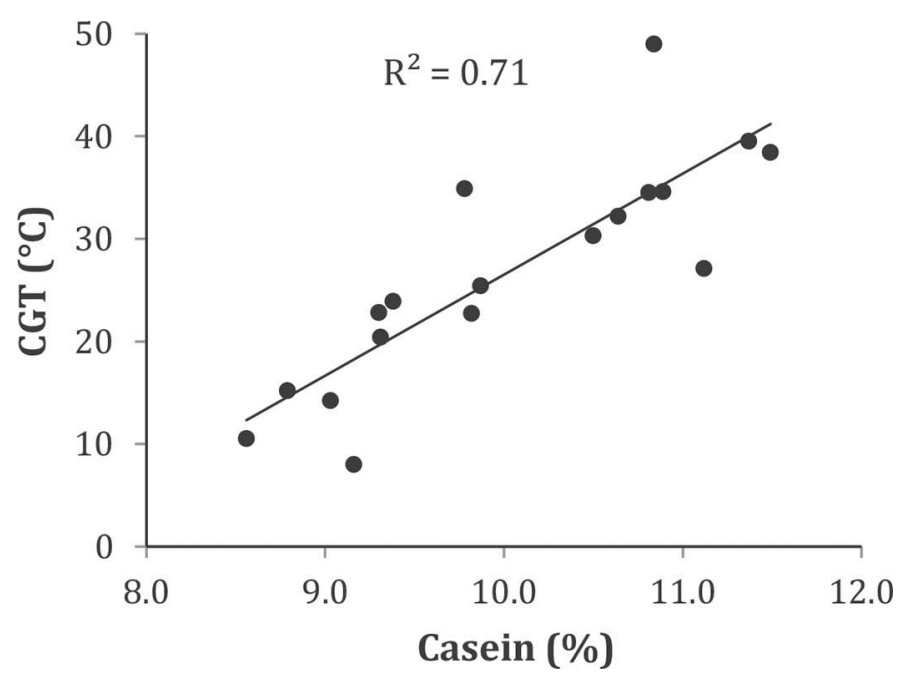

Figure 5. Cold-gelling temperature $\left(\mathrm{CGT},{ }^{\circ} \mathrm{C}\right)$ of recombined concentrated milk ( $\mathrm{pH} 7.0$ and protein to fat ratio of 0.8 ) at different casein levels, determined upon cooling from $50^{\circ} \mathrm{C}$ to $5^{\circ} \mathrm{C}$ at $1{ }^{\circ} \mathrm{C} / \mathrm{min}$ using a strain of $0.5 \%$ and a frequency of $1 \mathrm{~Hz}$.

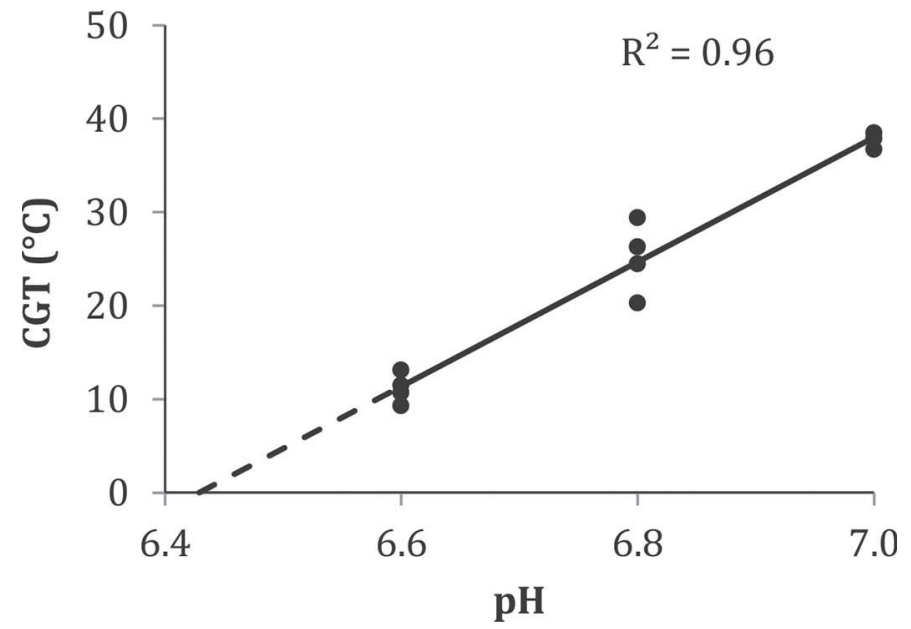

Figure 6. Cold-gelling temperature $\left(\mathrm{CGT},{ }^{\circ} \mathrm{C}\right)$ of recombined concentrated milk (12\% casein, protein to fat ratio of 1.2$)$ at $\mathrm{pH} 6.6,6.8$, and 7.0 , determined upon cooling from $50^{\circ} \mathrm{C}$ to $5^{\circ} \mathrm{C}$ at $1^{\circ} \mathrm{C} / \mathrm{min}$ using a strain of $0.5 \%$ and a frequency of $1 \mathrm{~Hz}$. Dashed line shows extrapolated trend line.

protein strands, which could enhance steric interference by increasing entanglement between different particles. This entanglement could further limit mobility of protein strands and form a 3-dimensional gel structure, resulting in cold gelation of RCM at higher temperature.

Effect of Calcium and Citrate. The CGT was linearly associated $\left(P<0.001, \mathrm{R}^{2}=0.81\right)$ with citrate addition (i.e., $0,0.13,0.26$, and $0.36 \mathrm{mmol} / \mathrm{g}$ of casein, Figure 7). For every $0.1 \mathrm{mmol} / \mathrm{g}$ of casein increase of added citrate, mean CGT increased about $6^{\circ} \mathrm{C}$. The ef-

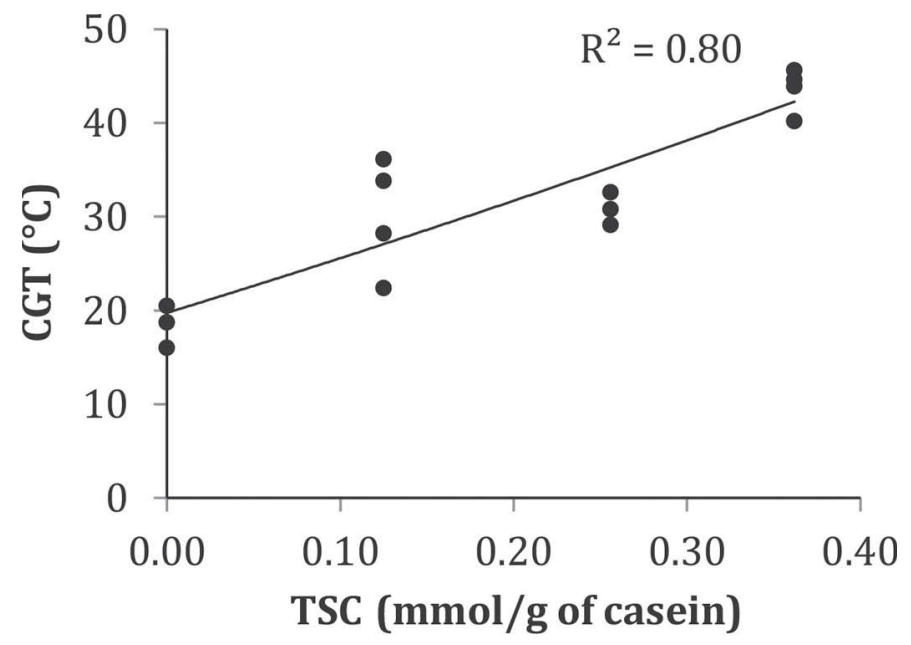

Figure 7. Cold-gelling temperature $\left(\mathrm{CGT},{ }^{\circ} \mathrm{C}\right)$ of recombined concentrated milk ( $12 \%$ casein, casein to fat ratio of 0.8 , and $\mathrm{pH} 6.6$ ) with addition of trisodium citrate (TSC, $\mathrm{mmol} / \mathrm{g}$ of casein) determined upon cooling from $50^{\circ} \mathrm{C}$ to $5^{\circ} \mathrm{C}$ at $1^{\circ} \mathrm{C} / \mathrm{min}$ using a strain of $0.5 \%$ and a frequency of $1 \mathrm{~Hz}$. 
fect of calcium addition to CGT varied at different addition levels. Adding $0.17 \mathrm{mmol}$ of calcium chloride/g of casein significantly $(P<0.05)$ increased CGT from 18 to $\geq 50^{\circ} \mathrm{C}$ (Figure 8 ). However, no significant change $(P>0.05)$ occurred in CGT when up to $0.12 \mathrm{mmol}$ of calcium chloride/g casein was added.

Addition of citrate has been reported to increase solubilization of casein micelles in HC-MCC gel, perhaps resulting from calcium-mediated protein linkage or dissociation of casein micelles (Lu et al., 2015). Addition of trisodium citrate has been associated with reducing levels of CCP through calcium chelation, resulting in dissociation of casein micelles in MPC (Kaliappan and Lucey, 2011). Dissociated casein micelles could increase entanglements of protein strands, resulting in increased steric interference and higher CGT.

The discontinuous change of CGT by addition of calcium indicates that cold gelation at low (i.e., $\leq 0.12$ $\mathrm{mmol} / \mathrm{g}$ of casein) and high calcium levels (i.e., $\geq 0.17$ $\mathrm{mmol} / \mathrm{g}$ of casein) are probably caused by different mechanisms. Addition of calcium at $\geq 0.17 \mathrm{mmol} / \mathrm{g}$ of casein could strengthen the gel by calcium-mediated protein linkage. Noncovalent bonding has been suspected to occur in HC-MCC gel and MPC powder (Anema et al., 2006; Havea, 2006; Lu et al., 2015). Increasing voluminosity and swelling of casein micelle has been observed upon addition of citrate, urea, or EDTA to casein micelle dispersions (Sood et al., 1979; Huppertz et al., 2007; de Kort et al., 2011). The calcium-mediated protein linkages could be weakened by addition of calci-

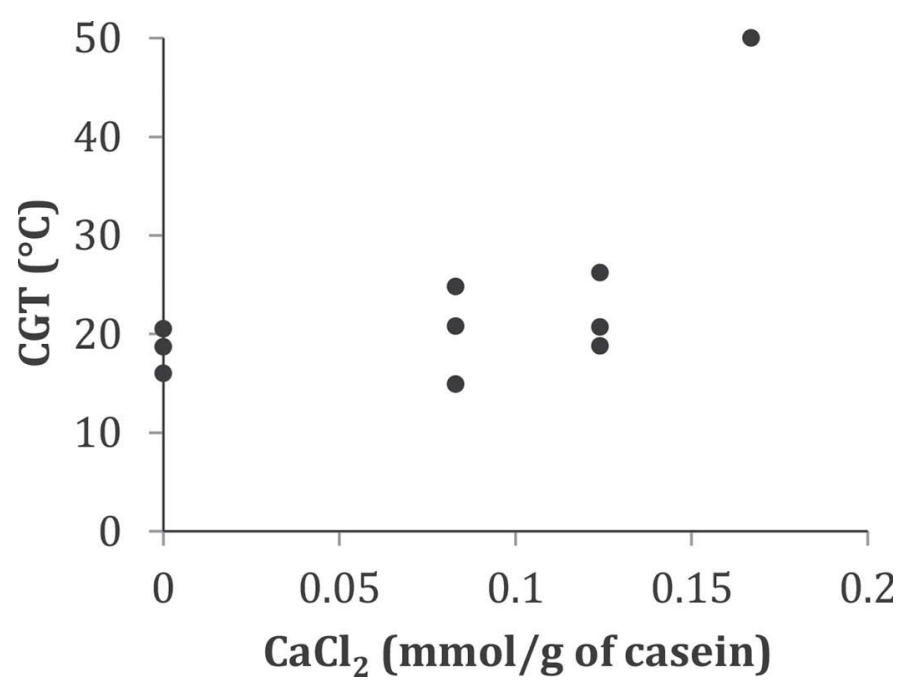

Figure 8. Cold-gelling temperature $\left(\mathrm{CGT},{ }^{\circ} \mathrm{C}\right)$ of recombined concentrated milk ( $12 \%$ casein, casein to fat ratio of 0.8 , and $\mathrm{pH} 6.6$ ) with addition of calcium chloride ( $\mathrm{mmol} / \mathrm{g}$ of casein) determined upon cooling from $50^{\circ} \mathrm{C}$ to $5^{\circ} \mathrm{C}$ at $1{ }^{\circ} \mathrm{C} /$ min using a strain of $0.5 \%$ and a frequency of $1 \mathrm{~Hz}$.

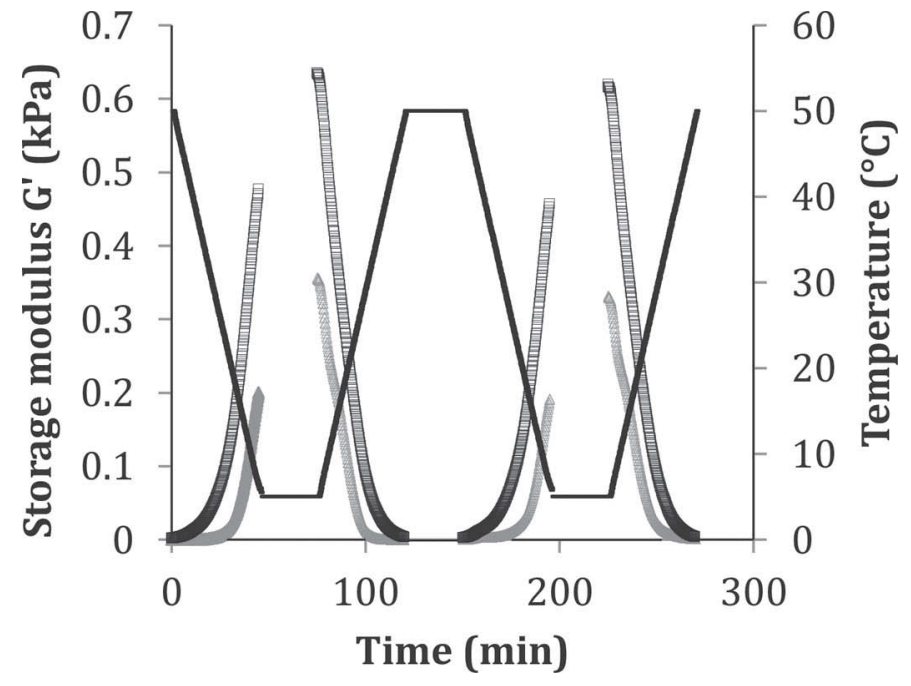

Figure 9. Storage modulus $\left(\mathrm{G}^{\prime}, \mathrm{kPa}\right)$ of recombined concentrated milk (10\% protein, protein to fat ratio of $0.8, \mathrm{pH}$ of 7.0$)$ during temperature cycling (solid line, right axis, ${ }^{\circ} \mathrm{C}$ ) with (black open square, left axis) or without (gray open triangle, left axis) addition of $0.08 \mathrm{mmol}$ of casein/g of trisodium citrate during temperature cycling (solid line, right axis) at $1^{\circ} \mathrm{C} / \mathrm{min}$ from $50^{\circ} \mathrm{C}$ to $5^{\circ} \mathrm{C}$ measured using $0.5 \%$ strain applied at $1 \mathrm{~Hz}$ frequency.

um chelators or be strengthened by addition of calcium. Strengthened interaction between casein micelles could cause aggregations of casein micelles, which agrees with the observation in transmission electron micrographs of RCM with calcium addition (Figure 1D, asterisks). The formation of aggregates expedites formation of a 3-dimensional gel structure at higher temperatures (i.e., resulting in higher CGT).

\section{Thermal Reversibility}

At $50^{\circ} \mathrm{C}, \mathrm{RCM}$ is fluid and when containing $10 \%$ protein it had $\mathrm{G}^{\prime}$ of $<0.1 \mathrm{~Pa}$ (Figure 9). Upon gelation and cooling to $5^{\circ} \mathrm{C}, \mathrm{G}^{\prime}$ was about $200 \mathrm{~Pa}$ and further increased to $360 \mathrm{~Pa}$ after holding at $5^{\circ} \mathrm{C}$ for $30 \mathrm{~min}$. Upon reheating to $50^{\circ} \mathrm{C}$, the mixture reliquefied, with $\mathrm{G}^{\prime}$ decreasing to $0.1 \mathrm{~Pa}$. When $\mathrm{RCM}$ was held at $50^{\circ} \mathrm{C}$ for $30 \mathrm{~min}$ and recooled, we observed the same pattern in $\mathrm{G}^{\prime}$.

Addition of $0.08 \mathrm{mmol}$ of trisodium citrate/g of casein to $\mathrm{RCM}$ increased $\mathrm{G}^{\prime}$ at $50^{\circ} \mathrm{C}>10$-fold to $2 \mathrm{~Pa}$. When cooled, $\mathrm{G}^{\prime}$ reached $480 \mathrm{~Pa}$ upon gelation and cooling to $5^{\circ} \mathrm{C}$, and further increased to $640 \mathrm{~Pa}$ after holding at $5^{\circ} \mathrm{C}$ for $30 \mathrm{~min}$. Upon reheating to $50^{\circ} \mathrm{C}$, $\mathrm{G}^{\prime}$ of the citrate-treated RCM decreased to $3 \mathrm{~Pa}$. The same pattern in $\mathrm{G}^{\prime}$ was observed after holding at $50^{\circ} \mathrm{C}$ for $30 \mathrm{~min}$, and recooling to $5^{\circ} \mathrm{C}$. At any specified temperature, $\mathrm{G}^{\prime}$ of $\mathrm{RCM}$ with citrate addition was higher than that without addition (Figure 9). These similar 
$\mathrm{G}^{\prime}$ patterns upon reheating or recooling cycles indicate that the cold gelation of RCM is thermally reversible, as was previously observed for HC-MCC (Lu et al., 2015).

\section{Casein Micelle Dissociation}

In our previous work ( $\mathrm{Lu}$ et al., 2015), we concluded that cold gelation of HC-MCC gel was attributed to steric interference of overlapping protuberances on the periphery of closely packed casein micelles. However, transmission electron micrographs of RCM indicate that casein micelles are no longer intact or closely packed. Instead, the casein micelles were extensively dissociated into loosely nonspherical aggregates and small protein strands, leaving empty channels in between (Figure 1C and E). In such a system, an increased volume might be occupied by proteins that dissociated from casein micelles, resulting in entanglements between small protein strands and dissociated casein micelles. These entanglements restrict the mobility of particles and cause gelation, especially at cold temperatures. Loose protein aggregates and nonspherical casein micelles have been observed in acidified skim milk at $10^{\circ} \mathrm{C}$, indicating that dissociation of casein micelles occurs at low temperatures (McMahon et al., 2009). This agrees with our observation that when increasing $\mathrm{pH}$ or adding citrate, dissociation of casein micelles is promoted, causing a higher degree of entanglement between proteins, resulting in cold gelation at a higher temperature.

The RCM of $4.6 \times$ concentration factor (i.e., $11.6 \%$ casein) with a casein-to-fat ratio of 0.8 and $\mathrm{pH}$ of 6.6 gelled at $18^{\circ} \mathrm{C}$. Similarly, Orme (1998) observed viscoelastic gel properties at low temperatures in a $5 \times$ whole-milk retentate $(\mathrm{pH}$ 6.6) produced by UF and diafiltration. The diafiltration process reduced calcium by about $50 \%$ in HC-MCC, which would decrease casein-bound calcium, resulting in dissociation of casein micelles. Interestingly, although some nonspherical casein micelles are present in HC-MCC gel, extensive dissociation of casein micelle has not been observed $(\mathrm{Lu}$ et al., 2015). A possible reason is that draining of water from the outer portion of casein micelles in HC-MCC probably occurs during the concentrating process, causing hydration spheres of casein micelles overlapping and leaving no room for any loosening of the casein micelle structure.

\section{CONCLUSIONS}

Understanding cold gelation of RCM and its rheological properties can help in designing process systems for using RCM as an ingredient in food applications. At $\mathrm{pH}$
6.6, an RCM with $12 \%$ casein does not gel until cooled below $12^{\circ} \mathrm{C}$ and so would not interfere with cheese making. If the $\mathrm{pH}$ is higher than 6.6 , then gelation occurs at higher temperatures unless the casein concentration is lowered. For example, at pH 7.0, RCM with $12 \%$ casein gels at $37^{\circ} \mathrm{C}$. Based upon the relationship between $\mathrm{pH}$ and CGT, we predicted that RCM with $12 \%$ casein would not gel even when cooled to $5^{\circ} \mathrm{C}$. Addition of either sodium citrate or high levels of calcium (i.e., $\geq 0.17 \mathrm{mmol} / \mathrm{g}$ of casein) increased CGT, although low levels of calcium (i.e., $\leq 0.12 \mathrm{mmol} / \mathrm{g}$ casein) did not affect CGT. Cold gelation of RCM was thermally reversible, even when citrate was added to partially chelate calcium. Compared with cold-gelled HC-MCC, in the cold-gelled RCM, the casein micelles were less closely packed together and appeared partially dissociated. We propose that cold gelation of RCM occurs when protein strands that have been partially released from the casein micelles entangle, restrict their mobility, and form a fine stranded gel network. Such a network consists of these fine strands of proteins as well as the modified casein micelles. In general, lowering the temperature, increasing $\mathrm{pH}$ above 6.6 , or chelating calcium accelerates dissociation of casein micelles. Formation of a gel network that depends upon entanglement of protein strands that are only loosely associated with the casein micelles would be favored when there is increased dissociation of casein micelles. When high levels $(21 \mathrm{mmol} / \mathrm{g}$ of casein) of calcium are added to RCM, the casein micelles are less dissociated but gelation is promoted, presumably through direct aggregation of casein micelles. Provided $\mathrm{pH}$ of RCM is not above the normal $\mathrm{pH}$ of milk, RCM at a casein level of $12 \%$ (wt/wt) has potential for use in cheese making.

\section{ACKNOWLEDGMENTS}

The authors are grateful to Lloyd E. Metzger (South Dakota State University, Brookings) and Anil Kommineni (South Dakota State University) for making and supplying the HC-MCC. We also thank Nabil N. Youssef (Utah State University, Logan) for suggestions on TEM sample preparation, Silvana Martini (Utah State University) for her assistance and advice in rheological measurements, the Aggie Creamery (Utah State University) for donating of cream and its staff for help with protein measurements, and the Electron Microscopy Core Research Facility at the University of Utah for use of the transmission electron microscope. Y. $\mathrm{Lu}$ was supported in her $\mathrm{PhD}$ studies by the Western Dairy Center (Logan, UT). Funding support was also provided by the Utah Agricultural Experiment Station, Utah State University, and approved as journal paper 
number 8767 . The use of trade names in this publication does not imply endorsement by Utah State University of the products named nor criticism of similar ones not mentioned.

\section{REFERENCES}

Amelia, I., and D. M. Barbano. 2013. Production of an 18\% protein liquid micellar casein concentrate with a long refrigerated shelf life. J. Dairy Sci. 96:3340-3349.

Amelia, I., M. Drake, B. Nelson, and D. M. Barbano. 2013. A new method for the production of low-fat Cheddar cheese. J. Dairy Sci. 96:4870-4884.

Anema, S. G., and H. Klostermeyer. 1997. Heat-induced, pH-dependent dissociation of casein micelles on heating reconstituted skim milk at temperatures below $100^{\circ} \mathrm{C}$. J. Agric. Food Chem. 45:11081115.

Anema, S. G., E. K. Lowe, S. K. Lee, and H. Klostermeyer. 2014. Effect of the $\mathrm{pH}$ of skim milk at heating on milk concentrate viscosity. Int. Dairy J. 39:336-343.

Anema, S. G., D. N. Pinder, R. J. Hunter, and Y. Hemar. 2006. Effects of storage temperature on the solubility of milk protein concentrate (MPC85). Food Hydrocoll. 20:386-393.

Bastian, E. D., K. G. Hansen, and R. J. Brown. 1991. Activation of plasmin with urokinase in ultrafiltered milk for cheese manufacture. J. Dairy Sci. 74:3669-3676.

Brandsma, R. L., and S. S. Rizvi. 2001. Manufacture of Mozzarella cheese from highly concentrated skim milk microfiltration retentate depleted of whey proteins. Int. J. Food Sci. Technol. 36:611624 .

Brandsma, R. L., and S. S. H. Rizvi. 1999. Depletion of whey proteins and calcium by microfiltration of acidified skim milk prior to cheese making. J. Dairy Sci. 82:2063-2069.

Creamer, L., M. Iyer, and J. Lelievre. 1987. Effect of various levels of rennet addition on characteristics of Cheddar cheese made from ultrafiltered milk. N.Z. J. Dairy Sci. Technol. 22:205-214.

de Kort, E., M. Minor, T. Snoeren, T. van Hooijdonk, and E. van der Linden. 2011. Effect of calcium chelators on physical changes in casein micelles in concentrated micellar casein solutions. Int. Dairy J. 21:907-913.

Ernstrom, C. A., B. J. Sutherland, and G. W. Jameson. 1980. Cheese base for processing. A high yield product from whole milk by ultrafiltration. J. Dairy Sci. 63:228-234

Farrell, H. M. Jr., T. F. Kumosinski, P. Pulaski, and M. P. Thompson. 1988. Calcium-induced associations of the caseins: A thermodynamic linkage approach to precipitation and resolubilization. Arch. Biochem. Biophys. 265:146-158.

Fox, P. F., T. P. Guinee, T. M. Cogan, and P. L. H. McSweeney. 2000. Principal families of cheese. Pages 388-428 in Fundamentals of Cheese Science. Aspen Publishers Inc., Gaithersburg, MD.

Garem, A., P. Schuck, and J.-L. Maubois. 2000. Cheesemaking properties of a new dairy-based powder made by a combination of microfiltration and ultrafiltration. Lait 80:25-32.

Govindasamy-Lucey, S., J. Jaeggi, A. Bostley, M. Johnson, and J. Lucey. 2004. Standardization of milk using cold ultrafiltration retentates for the manufacture of parmesan cheese. J. Dairy Sci. 87:2789-2799.

Govindasamy-Lucey, S., J. J. Jaeggi, M. E. Johnson, T. Wang, and J. A. Lucey. 2007. Use of cold microfiltration retentates produced with polymeric membranes for standardization of milks for manufacture of pizza cheese. J. Dairy Sci. 90:4552-4568.

Green, M. L., F. A. Glover, E. M. W. Scurlock, R. J. Marshall, and D. S. Hatfield. 1981. Effect of use of milk concentrated by ultrafiltration on the manufacture and ripening of Cheddar cheese. J. Dairy Res. 48:333-341.

Havea, P. 2006. Protein interactions in milk protein concentrate powders. Int. Dairy J. 16:415-422.

Hooi, R., D. M. Barbano, R. L. Bradley, D. Budde, M. Bulthaus, M. Chettiar, J. Lynch, and R. Reddy. 2004. Chemical and physical methods. Pages 363-536 in Standard Methods for the Examination of Dairy Products. 17th ed. H. M. Wehr and J. F. Frank, ed. American Public Health Association, Baltimore, MD.

Huppertz, T., M. A. Smiddy, and C. G. de Kruif. 2007. Biocompatible micro-gel particles from cross-linked casein micelles. Biomacromolecules 8:1300-1305.

Hurt, E., J. Zulewska, M. Newbold, and D. M. Barbano. 2010. Micellar casein concentrate production with a 3X, 3-stage, uniform transmembrane pressure ceramic membrane process at $50^{\circ} \mathrm{C}$. J. Dairy Sci. 93:5588-5600.

Hurt, E. E., M. C. Adams, and D. M. Barbano. 2015. Microfiltration of skim milk and modified skim milk using a $0.1-\mu \mathrm{m}$ ceramic uniform transmembrane pressure system at temperatures of 50,55 , 60, and $65^{\circ}$ C. J. Dairy Sci. 98:765-780.

Kaliappan, S., and J. Lucey. 2011. Influence of mixtures of calciumchelating salts on the physicochemical properties of casein micelles. J. Dairy Sci. 94:4255-4263.

Karlsson, A. O., R. Ipsen, and Y. Ardö. 2007. Observations of casein micelles in skim milk concentrate by transmission electron microscopy. LWT-. Food Sci. Technol. (Campinas.) 40:1102-1107.

Knudsen, J. C., and L. H. Skibsted. 2010. High pressure effects on the structure of casein micelles in milk as studied by cryo-transmission electron microscopy. Food Chem. 119:202-208.

Kosikowski, F. V., A. R. Masters, and V. V. Mistry. 1985. Cheddar cheese from retentate-supplemented whole milk. J. Dairy Sci. $68: 548-554$.

Lelievre, J., L. Creamer, and K. Tate. 1990. Inhibition of calf vell and microbial rennet action by whey protein concentrate. Milchwissenschaft 45:71-75.

Lu, Y., D. J. McMahon, L. E. Metzger, A. Kommineni, and A. H. Vollmer. 2015. Solubilization of rehydrated frozen highly concentrated micellar casein for use in liquid food applications. J. Dairy Sci. 98:5917-5930.

Lucey, J. A., and D. S. Horne. 2009. Milk salts: Technological significance. Pages 351-389 in Advanced Dairy Chemistry. Volume 3. Lactose, Water, Salts, and Minor Constituents. Vol. 3. 3rd ed. P. McSweeney and P. F. Fox, ed. Springer Science + Business Media LLC, New York, NY.

Marella, C., K. Muthukumarappan, and L. E. Metzger. 2013. Application of membrane separation technology for developing novel dairy food ingredients. J. Food Process. Technol. 4:269. 10.4172/21577110.1000269 .

McMahon, D. J., H. Du, W. McManus, and K. Larsen. 2009. Microstructural changes in casein supramolecules during acidification of skim milk. J. Dairy Sci. 92:5854-5867.

McMahon, D. J., and B. S. Oommen. 2008. Supramolecular structure of the casein micelle. J. Dairy Sci. 91:1709-1721.

McMahon, D. J., and B. S. Oommen. 2013. Casein micelle structure, functions, and interactions. Pages 185-209 in Advanced Dairy Chemistry. Vol 1A: Proteins: Basic Aspects. Vol. 1A. 4th ed. P. L. H. McSweeney and P. F. Fox, ed. Springer US, New York, NY.

Metzger, L. E., D. Barbano, M. Rudan, and P. Kindstedt. 2000. Effect of milk preacidification on low fat Mozzarella cheese. I. Composition and yield. J. Dairy Sci. 83:648-658.

Nelson, B. K., and D. M. Barbano. 2005. A microfiltration process to maximize removal of serum proteins from skim milk before cheese making. J. Dairy Sci. 88:1891-1900.

Neocleous, M., D. M. Barbano, and M. A. Rudan. 2002a. Impact of low concentration factor microfiltration on milk component recovery and cheddar cheese yield. J. Dairy Sci. 85:2415-2424.

Neocleous, M., D. M. Barbano, and M. A. Rudan. 2002b. Impact of low concentration factor microfiltration on the composition and aging of Cheddar cheese. J. Dairy Sci. 85:2425-2437.

Olson, D. W. 1992. Zeta-potential of casein micelles as a factor in age gelation of ultra-high temperature processed concentrated skim milk. MS Thesis. Utah State Univ., Logan.

Oommen, B. S. 2004. Casein supramolecules: Structure and coagulation properties. PhD Diss. Utah State Univ., Logan.

Orme, B. J. 1998. Improving fat retention and texture in low-moisture cheese manufactured from ultrafiltered milk. PhD Diss. Utah State Univ., Logan. 
Pierre, A., and G. Brule. 1981. Mineral and protein equilibria between the colloidal and soluble phases of milk at low temperature. J. Dairy Res. 48:417-428.

Pierre, A., J. Fauquant, Y. Le Graet, M. Piot, and J. Maubois. 1992. Préparation de phosphocaséinate natif par microfiltration sur membrane. Lait 72:461-474.

Post, A. E., B. Arnold, J. Weiss, and J. Hinrichs. 2012. Effect of temperature and $\mathrm{pH}$ on the solubility of caseins: Environmental influences on the dissociation of $\alpha_{S^{-}}$and $\beta$-casein. J. Dairy Sci. 95:1603-1616.

Saboyainsta, L. V., and J.-L. Maubois. 2000. Current developments of microfiltration technology in the dairy industry. Lait 80:541-553.

Singh, H., M. S. Roberts, P. A. Munro, and C. T. Teo. 1996. Acid-induced dissociation of casein micelles in milk: Effects of heat treatment. J. Dairy Sci. 79:1340-1346.

Sood, S., D. Gaind, and R. Dewan. 1979. Correlation between micelle solvation and calcium content. N.Z. J. Dairy Sci. Technol. $14: 32-44$.
St-Gelais, D., M. Piette, and G. Belanger. 1995. Production of Cheddar cheese using milk enriched with microfiltered milk retentate. A preliminary study. Milchwissenschaft 50:614-619.

Sutherland, B., and G. W. Jameson. 1981. Composition of hard cheese manufactured by ultrafiltration. Aust. J. Dairy Technol. 36:136143.

Upreti, P., L. McKay, and L. Metzger. 2006. Influence of calcium and phosphorus, lactose, and salt-to-moisture ratio on Cheddar cheese quality: Changes in residual sugars and water-soluble organic acids during ripening. J. Dairy Sci. 89:429-443.

van Leeuwen, H. J., N. H. Freeman, B. J. Sutherland, and G. W. Jameson. 1990. Preparation of hard cheese from concentrated milk. US Patent 4,965,078. Assignee, Commonwealth of Australia. 